\title{
Knowledge and Awareness of Papillomavirus and Cervical Cancer among College Students and Health Care Workers Women in Diyala, Iraq
}

\author{
Asmaa Haseeb Hwaid* \\ College of Education of Pure Science, Diyala University \\ *Corresponding author: asmaa.haseeb@ymail.com
}

Received November 10, 2013; Revised November 27, 2013; Accepted December 04, 2013

\begin{abstract}
Background: Human papillomavirus (HPV) is one of the most common causes of sexually transmitted infection and it's now known to be a risk factors for the development of cervical cancer. Cervical cancer is the second most common cancer in women and it's one of the leading causes of morbidity and mortality amongst the gynecological cancers worldwide, especially in developing countries. Objectives: This study sough to evaluate knowledge and awareness about Human Papillomavirus (HPV) and cervical cancer among women. Subjects and methods: The present study are cross sectional study was conducted in Diyala, Iraq during the period from 1/ November / 2012 to 30 / September / 2013, this study included 198 women, the mean age was (27.29 \pm 9.63 ) years, the age range was (17-60) years, the participants were divided into two groups, group I, (students group) includes (99) female college students who studies in Diyala university, group II, (health care workers group), includes (99) female physicians and nurses who worked in AL-Batol Maternity and Children Teaching Hospital. Data was collected using questionnaire that was adopted from previous studies. All data were statistically analysis. Results: The present results show that the women demonstrated poor levels of knowledge about HPV and cervical cancer, 106(53.54\%) of them had heard about HPV, while, only 73(36.87\%), 60(30.30\%) knew that the cervical cancer and genital warts caused by HPV respectively. This study showed that the participants had very limited knowledge about pap smear, only 57(28.79\%) knew that pap smear is the test to detect abnormal cervical cells, the results show highest level of knowledge and awareness about HPV, cervical cancer was among health care workers group, participants who live in urban and married with statistically significant difference $(\mathrm{P}<0.05)$, $(\mathrm{P}<0.01)$. Conclusion: This study highlights the need for educational programs regarding HPV infection and it's complications such as cervical cancer. In conclusion, the present study shows inadequate levels of knowledge and awareness about HPV and it's relation to cervical cancer, genital warts as well as transmission of infection and Pap smear test among study groups especially the university students.
\end{abstract}

Keywords: human papillomavirus (HPV), cervical cancer, knowledge, women

Cite This Article: Asmaa Haseeb Hwaid, "Knowledge and Awareness of Papillomavirus and Cervical Cancer among College Students and Health Care Workers Women in Diyala, Iraq.” American Journal of Public Health Research 1, no. 8 (2013): 221-225. doi: 10.12691/ajphr-1-8-5.

\section{Introduction}

Human papillomavirus (HPV) is a member of the papillomaviridae family of the viruses that are capable of infecting human and it's one of the most common causes of sexually transmitted diseases in both men and women worldwide [1]. In women, genital HPV types infect primarily the cervix, vagina, vulva and these genital type HPVs are further divided into high and low risk types according to the association with genital tract cancer [2]. High risk HPV types 16 and 18 causes cervical cancer, HPV 16 type is the most often found accounting for about half of the cervical cancer cases in the United State and Europe[3]. Transmission of the HPV occurs primarily by sexual contact or by skin to skin contact [4]. Cervical cancer and premalignant lesions constitute a major problem in women health according to the WHO, cervical cancer is the second most common cancer in women worldwide and is the most frequent cancer in many developing countries, with an estimate of about 493,243 women diagnosed with it and 273,505 dying from it per year, cervical cancer is also the world's second most frequent among women between 15 and 44 years of age $[5,6]$. The natural history of cervical cancer is a continuous disease process that progress gradually from mild cervical intraepithelial neoplasia (CIN) to more sever degrees of neoplasia (CIN 2 or CIN 3) and finally to invasive cancer [7]. Papanicolaou cytological testing (also called Pap smear) is a screening test used in gynecology to detect premalignant processes in the endocervical cancer, effectively reducing the incidence of the cervical cancer by $75 \%-90 \%$ [8]. In developing countries, only about $5 \%$ 
of women have been screened for the disease with pap smear compared to $40 \%-50 \%$ in developed countries[9]. In many developing countries, women's knowledge of cervical cancer and pap smear is very limited, in a survey performed in Nigeria, only 15\% had ever heard of cervical cancer, the knowledge of cervical cancer in Saudi Arabia is far behind that the developed countries, only 72 (14.4\%) of participants had knowledge that HPV is an etiological agent for cervical cancer [10,11,12,13]. Lack of knowledge and awareness about cervical cancer in most and screening programs contribute to high incidence of cervical cancer in most developing countries, and one of the most important tools of prevention is increasing awareness and knowledge among women [14], because there is no previous studies to evaluate the knowledge and awareness about HPV and cervical cancer among women of reproductive age, we conducted this study to assess levels of knowledge and awareness about HPV and cervical cancer among study groups.

\section{Method}

\subsection{Participants}

This study included 198 women, the mean age was $(27.29 \pm 9.63)$ years, the age range was $(17-60)$ years. these women were divided into two groups; group I, (students group) includes (99) of female students who studies in Diyala university (college of Medicine, college of Education, college of Science, and college of medical department of technical institute), group II, (health care workers group), includes (99) of female physician and nurses who worked in AL-Batool Maternity and Children Teaching Hospital.

\subsection{Measures}

The knowledge and awareness of HPV and cervical cancer

among participants women was measured using version of self-administered questionnaire (Appendix 1), this questionnaire was adopted from McPartland et al., [15] that created it to assess knowledge of HPV, and other studies $[16,23,24]$. The validity of the questionnaire was confirmed by two microbiologist professionals from the division of microbiology of the Medicine and Education for Pure Science College. The questionnaire was written in Arabic and then translated back into English. The questionnaire was divided into two sections to collect data on the following : (1) demographic characteristics and (2) seven questions that related to the knowledge of HPV infection and cervical cancer, these questions evaluating knowledge were " Yes / No / Don’t know pattrens".

\subsection{Procedure}

The present study are across sectional study was conducted in Baqubah-Diyala province during the period from 1 November / 2012 to 30 / September / 2013. A face to face interview was performed and all the participants in this study gave prior approval before the interview started, after the interview, the participants received details counseling about HPV infection and cervical cancer. The
Diyala university and AL-Batool Maternity and Children Teaching Hospital approved the study.

\subsection{Data Analysis}

Statistical analysis was performed using SAS version 11 Ed. (Inst. Inc, Cary, NC, USA) Chi-square test was used to compare between different variables according to the correct answer to the question only and P - value of < 0.05 was considered significance.

\section{Results}

One hundred and ninety-eight women were included in this study. The quantitative baseline data of the participants which are : mean age, groups, residence and material status are shown in the Table 1 bellow.

Table 1. Baseline data of participants

\begin{tabular}{|c|c|c|}
\hline Variables & Frequency & $\%$ \\
\hline Mean age & \multicolumn{2}{|c|}{$(27.29 \pm 9.63)$} \\
\hline Groups & \multicolumn{2}{|c|}{} \\
College tudent group & 99 & $50 \%$ \\
Health care workers group & 99 & $50 \%$ \\
\hline Residence & 124 & $62.62 \%$ \\
Urban & 74 & $37.37 \%$ \\
Rural & 127 & $64.14 \%$ \\
Married status & 71 & $35.85 \%$ \\
Single & 198 & $100 \%$ \\
\hline Married & & \\
\hline Total & &
\end{tabular}

The quantitative results of investigating the levels of the knowledge of HPV infection and cervical cancer among participants women are illustrated in Table 2 below:

Table 2. Knowledge of HPV infection and cervical cancer among participants

\begin{tabular}{|c|c|c|c|c|}
\hline & Questions & Yes & No & Don't know \\
\hline Q1 & $\begin{array}{c}\text { Have you heard } \\
\text { about } \\
\text { Papillomavirus } \\
\text { before? }\end{array}$ & $106(53.54 \%)$ & $59(29.80 \%)$ & $33(16.66 \%)$ \\
\hline Q2 & $\begin{array}{c}\text { Is Papillomavirus } \\
\text { causes cervical } \\
\text { cancer? }\end{array}$ & 73(36.87\%) & 18(9.09\%) & $107(54.04 \%)$ \\
\hline Q3 & $\begin{array}{c}\text { Is Papillomavirus } \\
\text { causes genital } \\
\text { warts or anal } \\
\text { warts? }\end{array}$ & $60(30.30 \%)$ & $23(11.62 \%)$ & $115(58.08 \%)$ \\
\hline Q4 & $\begin{array}{l}\text { Is Papillomavirus } \\
\text { transmitted by } \\
\text { sexual contact? }\end{array}$ & $70(35.35 \%)$ & $31(15.66 \%)$ & 97(48.99\%) \\
\hline Q5 & $\begin{array}{l}\text { Is the (pap smear) } \\
\text { special test to } \\
\text { detect abnormal } \\
\text { cervical cell? }\end{array}$ & $57(28.79 \%)$ & $18(9.09 \%$ & $123(62.12 \%)$ \\
\hline Q6 & $\begin{array}{l}\text { Is the smoking } \\
\text { increases the risk } \\
\text { of cervical cancer? }\end{array}$ & $114(57.58 \%)$ & $10(5.05 \%)$ & $74(37.37 \%)$ \\
\hline Q7 & $\begin{array}{l}\text { Is the vaccine for } \\
\text { the prevention of } \\
\text { the disease } \\
\text { available? }\end{array}$ & $46(23.23 \%)$ & $35(17.68 \%)$ & $117(59.09 \%)$ \\
\hline
\end{tabular}

The results show higher knowledge about HPV, cervical cancer, genital warts, transmission was noticed among health care workers in comparison with college students with statistically significant difference $(\mathrm{P}<0.05)$, $(\mathrm{P}<0.01)$, Table 3 . 
Table 3. Comparison between health care workers group and college students group according to answer of question -yes (percentage)

\begin{tabular}{|c|c|c|c|}
\hline \multirow{2}{*}{ Question } & \multicolumn{2}{|c|}{ Percentage (\%) } & \multirow{2}{*}{$\begin{array}{c}\text { Chi-square } \\
\text { value }\end{array}$} \\
\cline { 2 - 3 } & $\begin{array}{c}\text { Health care workers } \\
\text { group }\end{array}$ & $\begin{array}{c}\text { College students } \\
\text { group }\end{array}$ & $6.768 * *$ \\
\hline Q1 & 35.86 & 17.68 & $6.083 * *$ \\
\hline Q2 & 28.28 & 8.59 & $4.761 *$ \\
\hline Q3 & 23.74 & 6.57 & $5.149 *$ \\
\hline Q4 & 26.77 & 8.59 & NS \\
\hline Q5 & 17.68 & 11.11 & NS \\
\hline Q6 & 30.80 & 26.77 & NS \\
\hline Q7 & 11.62 & 11.62 & \\
\hline & \multicolumn{2}{|c|}{$*(\mathrm{P}<0.05), * *(\mathrm{P}<0.01)$} & \\
\hline
\end{tabular}

Regarding the residency, Table 4, show that the knowledge of HPV, cervical cancer, genital warts, transmission, pap smear test and risk factors (smoking) that increases risk of cervical cancer and vaccine was significantly higher among urban participants in comparison with rural participants $(\mathrm{P}<0.05)$, $(\mathrm{P}<0.01)$.

Table 4. Effect of residence according to answer of question -yes (percentage)

\begin{tabular}{|c|c|c|c|}
\hline \multirow{2}{*}{ Question } & \multicolumn{2}{|c|}{ Percentage (\%) } & \multirow{2}{*}{ Chi-square value } \\
\cline { 2 - 3 } & Urban & Rural & \\
\hline Q1 & 34.85 & 18.69 & $6.452 * *$ \\
\hline Q2 & 24.75 & 12.12 & $4.618 *$ \\
\hline Q3 & 21.72 & 8.59 & $4.742 *$ \\
\hline Q4 & 25.25 & 10.10 & $3.780 *$ \\
\hline Q5 & 20.20 & 8.59 & $4.271 *$ \\
\hline Q6 & 20.20 & 8.59 & $4.271 *$ \\
\hline Q7 & 20.20 & 8.59 & $4.271 *$ \\
\hline \multicolumn{4}{|c|}{$*(\mathrm{P}<0.05),{ }^{* *}(\mathrm{P}<0.01)$} \\
\hline
\end{tabular}

The present results show that the knowledge of cervical cancer as a results of HPV infection was significantly higher among married women in comparison with single women $(\mathrm{P}<0.05)$, Table 5.

Table 5. Effect of marriage according to answer of question -yes (percentage)

\begin{tabular}{|c|c|c|c|}
\hline \multirow{2}{*}{ Question } & \multicolumn{2}{|c|}{ Percentage (\%) } & \multirow{2}{*}{ Chi-square value } \\
\cline { 2 - 3 } & Married & Single & \\
\hline Q1 & 28.28 & 25.25 & NS \\
\hline Q2 & 22.22 & 14.65 & $3.985^{*}$ \\
\hline Q3 & 18.69 & 11.62 & NS \\
\hline Q4 & 20.71 & 14.65 & NS \\
\hline Q5 & 14.65 & 14.14 & NS \\
\hline Q6 & 21.72 & 35.86 & $4.537^{*}$ \\
\hline Q7 & 6.57 & 16.67 & $3.965 *$ \\
\hline \multicolumn{3}{|c}{$(\mathrm{P}<0.05)$} \\
\hline
\end{tabular}

\section{Discussion}

This study is the first study to evaluate the levels of knowledge and awareness about HPV and cervical cancer among female college students and health care workers in Diyala society. The results show, in accordance with Original Bloom's Cut Off Points [16] (Appendix 2), that the participants women, generally, have poor levels of knowledge and awareness about HPV, cervical cancer, transmission of infection, pap smear test that used to detect infection, risk factors (smoking) and vaccine .

The results showed that 106(53.54\%) of the respondents had heard about papillomavirus HPV, while, previous study that conducted in California on students females show higher knowledge rate about HPV (75.5\%) [17]. Another study conducted in Natal, Brazil, showed that most participants (70.9\%) had poor levels of knowledge about HPV [18]. In a study that conducted on Chinese and African undergraduate medical student, Mpemba et al., [19] found that (61.2\% and 58.5\%) knew about HPV. The majority of participants had a very low knowledge levels about cervical cancer that caused by HPV infection, only 73(36.87\%) of them correctly answered, In Qatar, AL-Meer et al., [20] found that just over (85\%) had heard about cervical cancer. The results showed a deficiency levels of knowledge about genital warts, only $60(30.30 \%)$ of the participants knew that HPV infection causes genital warts, a study preformed in Michigan university revealed similar results, only (33.8\%) knew that HPV infection causes genital warts [21]. Only $70(35.35 \%)$ of the women respondents knew that HPV is a sexually transmitted agent, different studies had yielded different results, for instance, Lima et al ., [18] found that (20.0\%) of the women knew that HPV transmitted by sexual contact, In Colombia, (80.2\%) of respondents didn't knew that HPV was sexually transmitted [22], while in Thailand, Phianmongkhol et al., [23] reported higher levels of knowledge (83.2\%) among nurses.

This study showed that the women had very limited knowledge and aware about pap smear test, only (28.79\%) correctly answered that pap smear is the test that used to detect abnormal cervical cells (precancerous cells), another studies in Qatar, Saudi Arabia and Kenya, Barazil reported higher levels of knowledge and aware about pap smear test $(76 \%, 67.7 \%, 75 \%, 68.9 \%)$ respectively $[20,24,25,26]$. Concerning the smoking, $114(57.58 \%)$ of participants correctly answered that the smoking increasing the risk of cervical cancer, the knowledge about smoking as a risk factors was different from one study to another, for instance, Ali et al., [27] found that (7\%) of the respondents knew that the smoking increasing the risk of cervical cancer, In Thailand, Phianmongkhol et al., [23] reported higher knowledge level about the smoking.

The highest levels of knowledge about HPV, cervical cancer, genital warts, transmission, pap smear test, smoking, and vaccine was among urban in comparison with rural participants with statistically significant difference $(\mathrm{P}<0.05)$, $(\mathrm{P}<0.01)$. Regarding the married status, the present study show higher knowledge and awareness about cervical cancer and vaccine was among married women with statistically significant difference $(\mathrm{P}<0.05)$, this findings are consistent with the results of AL-Meer et al., [20] that found higher knowledge and awareness about cervical cancer was significantly greater among married women. Regarding the levels of knowledge about HPV infection and cervical cancer and probably the general health education among rural women in Diyala society is low compared to that among women in urban areas, which are more civilities. Actually, there are many reasons behind that including limited number of schools, social stigma, religious commitment and poor 
access to the media, likewise, and for some reasons, single women have little or poor knowledge about their genital tract and the disease that may have adversity affect on this system. Moreover, because of social traditions, it is a sort of shame for unmarried women to seeking such knowledge.The present study results are consistent with the findings of Sait, [24] that showed highest levels of knowledge and awareness about HPV, cervical cancer, genital warts, transmission of infection was among health care workers in comparison with students with statistically significant difference $(\mathrm{P}<0.01)$.

\section{Conclusion}

The present study shows inadequate levels of knowledge and awareness about (HPV), cervical cancer, genital warts, transmission of infection and Pap smear test among study groups especially the college students. Infection of HPV and it's complications such as cervical cancer have adversity affect on women. Education and screening programs are needed to prevent HPV infection.

\section{Acknowledgement}

The author would like to thank the professor AbulRazak Shafiq Hasan, College of Medicine and Abbas Abood Al-Duliami, College of Education of Pure Science for their support.

\section{References}

[1] Brooks, G. F.; Carrol, K. C.; Butel, J. S. and Mores, S. A. Papillomavirus. In: Medical Microbiology. Brooks, G. F.; Carrol, K. C.; Butel, J. S. and Mores, S. A. (eds). $24^{\text {th }}$ Ed. The McGrawHill Companies, Inc. 2007; P: 597-600.

[2] Gnanamony, M. P. A. and Abraham, P. An overview of human Papillomavirus and current vaccine strategies. Indian. Journal. Medical. Microbiology. 2007; 25(1):10-17.

[3] Anorlu, R. I. Cervical cancer: the Sub-Saharan African perspective. Reported. Health. Matters. 2008; 16(32):41-9.

[4] Levinson, W. Human Papillomavirus. In: Review of Medical Microbiology and Immunology. Levinson, W (eds). $10^{\text {th }}$ Ed. The McGraw - Hill Companies, Inc. 2008; p: 264-265.

[5] Parkin, D. M. ; Ferlay, B. J. and Pisani, P. Global cancer statistics . Journal of clinical virology. 2005; 55(2):74-108.

[6] WHO. Cervical cancer screening in developing countries. Report of the World Health Organization Consultation. Consulted. 2002; 14.09.2010.

[7] Saonere, A. J. Awareness screening programs reduces the risk of cervical cancer in women. African Journal of Pharmacy and Pharmacology. 2010; 4(6): 314-23.

[8] Rod, B. and Cole, P. The fifty-year decline of cancer in America. $J$. Clin. Oncol. 2001; 19: 239-41.

[9] Musmar, S. G. Pattern and factors affecting pap smear test in Nabuls, a retrospective study. Middle East Journal of Family Medicine. 2004; 4(4).

[10] Kidanto HL, Kilewo CD, Moshiro C. Cancer of the cervix: knowledge and attitudes of female patients admitted at Muhimbili National Hospital, Dar es Salaam. East African Medical Journal, 2002; 79(9):745-46.

[11] Ayayi IO, Adewole IF. Knowledge and attitude of general outpatient attendants in Nigeria to cervical cancer. Central African Journal of Medicine, 1998, 44(2):41-43.

[12] Amarin, Z.O; Badria, L.F. and Obeidat, B.R. Attitudes and beliefs about cervical smear testing in ever-married Jordanian women. Eastern Mediterranean Health Journal, 2008; 14(2): 389-97.
[13] Sait, KH. Attitudes, Knowledge and Practices in relation to cervical cancer and its screening among women in Saudi Arabia. Saudi. Med. J. 2009; 30(9):1208-12.

[14] Gronje, H. S. Screening for cervical cancer in developing world. Best. Pract. Res. Clin. Obestet. Gynaecol. 2005; 19(4): 517-29.

[15] McPartland, T.; Weaver, S. and Koutsky, K. Men's perception and knowledge of Human Papillomavirus (HPV) infection and cervical cancer. Journal of American College Health. 2005; 53: 225-30.

[16] Johon, J. The knowledge and attitudes, practice and perceived barriers towards screening for premalignant cervical lesions among women aged 18 years and above, In Songea Urban, Ruvuma. Thesis. Muhimbili University of Health and Ahied Science. 2011.

[17] Lopez, R. and McMahan, S. College Women's Perception and Knowledge of human Papillomavirus (HPV) and cervical cancer. Californian Journal of Health Promotion. 2007; 5(3): 12-25.

[18] deLima, É. G. ; Soares de Lima, D. B. ; Miranda, C. A. N. ; Pereira, V. S. ; Azevedo, J. C. V. et al. Knowledge about HPV and Screening of Cervical Cancer among Women from the Metropolitan Region of Natal, Brazil. Obstetrics and Gynecology. 2013.

[19] Mpemba, F.; Kampo, S. and Zhang, X. Knowledge and attitude of HPV among Chinese and African undergraduate medical students studying in China. Journal of Education Research and Behavioral Sciences. 2013; Vol. 2(5): 58-67.

[20] Al-Meer, F.M.; Aseel, M.T.; Al-Khalaf, J.; et al. Knowledge, attitude and practices regarding cervical cancer and screening among women visiting primary health care in Qatar. East. Meditt. Health. J. 2011; 17(11).

[21] Holcomb, B. ; Bailey, J.M.; Grawford, K. and Ruffin IV, M.T. Adult's knowledge and Behaviors Related to human Papillomavirus infection. JABFP. 2004; 17(1):26-31.

[22] Hanisch, R. ; Gustat, J. ; Hagensee, M. E. ; Baene, A. ; Salazar, J. E. ; et el. Knowledge of pap smear screening and human papillomavirus among women attending clinics in Medellina, Colombia. Int. J. Gynecol. Cancer. 2008 Sep-Oct; 18(5):1020-6.

[23] Phianmongkhol,Y. ; Suwan, N.; Srisomboon, J. and Kietpeerakool, C. Knowledge about Human Papillomavirus Infection and Cervical Cancer Prevention among Nurses in Chiang Mai University Hospital, Thailand. Asian Pacific Journal of Cancer Prevention. 2011; Vol 12: 823-25.

[24] Sait, K. H. Knowledge, Attitudes and practices regarding cervical cancer screening among physicians in Western Region of Saudi Arabia. Saudi. Med. J. 2011; 32(11):1155-60.

[25] Elizabeth, O. ; Anne, M. and Peter, W. Awareness of cervical cancer risk factors and practice of pap smear testing among female primary school teachers in Kasarani division, Nairobi, Kenya. African Journal of Health Sciences. 2012; 21(2):121-32.

[26] de Lima, D. B. S. ; Carvalho, M, G, F. ; Fernandes, T. A. A. ; de Araújo, J. M. G; de Azevedo, p. R. M. ; et al. Knowledge, Attitudes and practice related to pap test and HPV among adolescents in NATAL, BRAZIL. British Journal of Medical and Health Sciences. 2013; 1(6): 01-14.

[27] Ali, S. F. ; Afif, M. et al. Knowledge and awareness about cervical cancer and it's preventation amongst interns and nursing staff in Tertiary care hospitals in Karachi, Pakistan. Journal. pone. 2010; 5(6).

\section{Appendix 1}

\section{Questionnaire}

\begin{tabular}{|c|c|}
\hline Socio-demographic characteristic & $\begin{array}{c}\text { Number of } \\
\text { questionnaire }\end{array}$ \\
\hline AGE & \\
\hline EDUCATION & \\
\hline MARRID & \\
\hline NON MARRIED & \\
\hline RESIDENCE & \\
\hline SMOKER & \\
\hline NON-SMOKER & \\
\hline
\end{tabular}


Questions related to the knowledge and awareness

\begin{tabular}{|c|c|c|c|c|}
\hline $\begin{array}{l}\text { Have you heard } \\
\text { about papilloma } \\
\text { virus before? }\end{array}$ & Yes--------------- & No----- & $\begin{array}{l}\text { Don’t } \\
\text { Know ------ }\end{array}$ & -1 \\
\hline $\begin{array}{l}\text { Is Papilloma virus } \\
\text { causes cervical } \\
\text { cancer? }\end{array}$ & Yes----- & No----- & $\begin{array}{l}\text { Don’t } \\
\text { Know ------ }\end{array}$ & -2 \\
\hline $\begin{array}{l}\text { Is Papilloma virus } \\
\text { cause genital or anal } \\
\text { warts? }\end{array}$ & Yes---. & No----- & $\begin{array}{l}\text { Don’t } \\
\text { Know ------ } \\
\end{array}$ & -3 \\
\hline $\begin{array}{l}\text { Is Papilloma virus } \\
\text { transmitted by } \\
\text { sexual? }\end{array}$ & Yes---- & No----- & $\begin{array}{l}\text { Don't } \\
\text { Know ------ } \\
--------- \\
\end{array}$ & -4 \\
\hline $\begin{array}{l}\text { Is the (Pap smear) } \\
\text { special test to detect } \\
\text { abnormal cervical } \\
\text { cells? }\end{array}$ & Yes---. & No----- & $\begin{array}{l}\text { Don’t } \\
\text { Know ------ }\end{array}$ & -5 \\
\hline $\begin{array}{l}\text { Is Smoking is one of } \\
\text { the factors affecting } \\
\text { the increase of } \\
\text { dangerous disease? }\end{array}$ & Yes--------------- & No----- & $\begin{array}{l}\text { Don’t } \\
\text { Know ------ }\end{array}$ & -6 \\
\hline $\begin{array}{l}\text { Is the vaccine for the } \\
\text { prevention of the } \\
\text { disease available? }\end{array}$ & Yes--------------- & No----- & $\begin{array}{l}\text { Don’t } \\
\text { Know ------ } \\
--------- \\
\end{array}$ & -7 \\
\hline
\end{tabular}

Appendix 2

Original Bloom's Cut Off Points [16]

$80-100 \%$ ( Good Knowledge )

$60-79 \%$ (Moderate Knowledge ) 